IZA DP No. 7423

Are You Unhappy Having Minority Co-Workers?

Getinet Haile

May 2013 


\title{
Are You Unhappy Having Minority Co-Workers?
}

\author{
Getinet Haile \\ Nottingham University Business School \\ and IZA
}

Discussion Paper No. 7423

May 2013

IZA
P.O. Box 7240
53072 Bonn
Germany

Phone: +49-228-3894-0

Fax: +49-228-3894-180

E-mail: iza@iza.org

Any opinions expressed here are those of the author(s) and not those of IZA. Research published in this series may include views on policy, but the institute itself takes no institutional policy positions. The IZA research network is committed to the IZA Guiding Principles of Research Integrity.

The Institute for the Study of Labor (IZA) in Bonn is a local and virtual international research center and a place of communication between science, politics and business. IZA is an independent nonprofit organization supported by Deutsche Post Foundation. The center is associated with the University of Bonn and offers a stimulating research environment through its international network, workshops and conferences, data service, project support, research visits and doctoral program. IZA engages in (i) original and internationally competitive research in all fields of labor economics, (ii) development of policy concepts, and (iii) dissemination of research results and concepts to the interested public.

IZA Discussion Papers often represent preliminary work and are circulated to encourage discussion. Citation of such a paper should account for its provisional character. A revised version may be available directly from the author. 


\section{ABSTRACT}

\section{Are You Unhappy Having Minority Co-Workers?*}

This paper attempts to establish empirically whether natives' job satisfaction is adversely affected by having minority co-worker(s). The paper uses nationally representative linked employer-employee data and eight different facets of job satisfaction. Measuring minority coworker status at the workplace- and occupation-level and employing alternative econometric estimators; the paper finds that on average natives' experience a reduction in job satisfaction due to having minority co-worker(s). The effect found is larger if the co-worker-ship is at the occupation-level.

JEL Classification: J7, J15, J82, I31

Keywords: discrimination, job-related well-being, linked employer-employee data, Britain

Corresponding author:

Getinet Haile

Nottingham University Business School

Jubilee Campus

Nottingham, NG8 1BB

United Kingdom

E-mail: getinet.haile@nottingham.ac.uk

\footnotetext{
${ }^{*}$ Paper to be presented at the $10^{\text {th }}$ IZA Annual Migration Meeting in Jerusalem, Israel. The author is grateful to the Economic and Social Research Council for part funding of this research from the research grant RES-000-22-2465. The author also acknowledges the Department of Trade and Industry, the Economic and Social Research Council, the Advisory, Conciliation and Arbitration Service and the Policy Studies Institute as the originators of the 2004 Workplace Employment Relations Survey data, and the Data Archive at the University of Essex as the distributor of the data. The National Centre for Social Research was commissioned to conduct the survey fieldwork on behalf of the sponsors. None of these organisations bears any responsibility for the author's analysis and interpretations of the data.
} 


\section{Introduction}

This paper investigates whether having minority co-worker(s) has some implications for the job satisfaction of natives (whites). There are several reasons why such a study may be essential. First, there is a large body of evidence on ethnic discrimination in Britain (for example, Clark and Drinkwater 2007, Frijters et al. 2006, Blackaby et al. 2005, Shields and Price 2002) despite legislations aimed at curbing discrimination on the basis of race/ethnicity that have been in place for over halfcentury. ${ }^{\mathrm{i}}$ Second, there is evidence that the proportion of minorities in the labour market and workplaces in Britain has steadily increased through successive inflows of migrants after World War II and due to globalisation in more recent decades (Clark and Drinkwater 2007, Strategy Unit 2003). This increase in the proportion of minorities may contribute to a reduction in the job satisfaction of natives, if minorities were to be viewed as threats; and ethnic discrimination may be a manifestation of this. Third, studies on ethnic minority workers focus on employment disadvantages in the form of ethnic penalty in employment and earnings for the most part. Aside from Frijters et al. (2006), there is hardly any evidence relating to whether workplace ethnic composition in Britain has any bearing on the job satisfaction of employees in general and natives in particular. It is vital that research fills this gap to help inform the design of appropriate measures aimed at addressing adverse consequences that may be linked to workplace ethnic composition.

The paper has several strengths. First, it uses the WERS2004 data, a nationally representative linked employer-employee data. The data have large number of demographically varied workplaces located across Britain and offer the scope for studying whether workplace ethnic composition has any bearing on the job satisfaction of natives. The linked data also have comprehensive information on employees and their workplaces, including information on local areas of the workplaces, which permit controlling for a wide range of influences. Secondly, the data have eight different facets of job-related satisfaction. This enables investigating links between workplace ethnic composition and aspects of job satisfaction hither to unexplored. Third, the paper deploys alternative markers of minority co-worker status, which are defined both at the workplace- and occupation-level based on responses of both employers and employees. Fourth, the paper also employs alternative empirical approaches. The use of alternative 
markers of minority status and alternative empirical strategies are likely to help establish the robustness of the link between job satisfaction and having minority co-worker(s).

\section{Related literature}

The proportion of ethnic minorities has been increasing in Britain. ${ }^{\text {ii }}$ Notwithstanding the evidence on ethnic penalty in labour market outcomes, a corresponding increase in the proportion of minorities in workplaces is to be expected. Despite this, there is a dearth of empirical evidence on the relationship between ethnic composition and job satisfaction at the workplace-level in particular. Job satisfaction is an integral part of overall well-being; given ( $\imath$ the amount of time spent at work by most (full-time employed) people and (ii) the central role that employment plays in the life of most people (Warr 1999). As such, establishing whether there is a link between workplace ethnic composition and employee job satisfaction will be informative from the viewpoint of addressing issues of employee well-being. Crucially, there could be circumstances under which adverse consequences of workplace ethnic composition on job-related well-being could be positive. iii

The limited existing evidence points to widespread labour market discrimination on the grounds of race and/or ethnicity in Britain despite legislations meant to overcome them, which lasted for over half-century. Berthoud and Blekesaune (2007) use data from the General Household Survey covering the period 1974 to 2003 and report about the employment penalty faced by ethnic minorities. They note a general decline in employment disadvantage for ethnic minorities since the mid-1990s; but with considerable variation among different ethnic minority groups, some faring considerably worse. Clark and Drinkwater (2007) also come to a similar conclusion of a general improvement in employment outcomes for ethnic minorities between on the basis of Census microdata from 1991 and 2001; but warn that "it would be extremely misleading to suggest that such progress has eliminated ethnic minority employment disadvantage" (p. 45).

Shields and Price (2002) use data from a 1994 large-scale survey of British NHS nurses to investigate perceived racial harassment at the workplace and its impact on ethnic minority nurses' job satisfaction and quitting behaviour. They note that nearly $40 \%$ and more than $64 \%$ of ethnic minority nurses report experiencing racial harassment from work colleagues and patients, respectively. The study finds the adverse experience 
of minority nurses having detrimental effect on their job satisfaction, resulting in increased probability of quitting the NHS. Pudney and Shields (2000) also use the same data on NHS nurses to establish the extent of gender and race disadvantage in the promotion process of NHS nurses and implied earnings penalty. Although they caution about attributing 100 per cent of the implied earnings differential to labour market discrimination, they report "there is also a clear evidence of an advantage for white over black or Asian nurses, implying a life-time earnings loss for black and Asian nurses of between $£ 26,000$ and $£ 35,000$ for females and between $£ 30,000$ and $£, 38,000$ for males" (p. 824).

Blackaby et al. (2005) use data from the UK Labour Force Survey over the period 1993 to 2000 to compare employment and earnings outcomes between male British-born ethnic minorities and their white counterparts. They find substantial earnings and employment gaps between the two groups, which led them to conclude that British-born ethnic minorities fare little better than their immigrant parents. By focusing on British born ethnic minorities, the study is able to rule out non-ethnic factors identified in the literature as explaining gaps in labour market outcomes between whites and minorities such as language (Leslie and Lindley 2001), schooling (Blackaby et al. 2002) and customs and network (Frijters et al. 2003). Blackaby et al. (2005) do not rule out the role segregation among some ethnic (and religious) communities might have played in explaining ethnic penalty in labour market outcomes. Nevertheless, the finding that British-born ethnic minorities fare poorly weakens assertions made elsewhere concerning improvements in disadvantages ethnic minorities, including foreign born ones, face.

Frijters et al. (2006) investigate the link between workplace ethnic composition and job satisfaction using the 1998 linked employer-employee data (WERS1998). They develop two testable hypotheses, which are both based on 'employee taste for discrimination' explanation, viz., (a) whether white workers experience lower job satisfaction the higher the proportion of ethnic minorities in workplaces and (b) whether white workers need to be compensated for by higher wages for having ethnic coworkers. They find "clear evidence" in support of the two hypotheses they developed. Specifically, that job satisfaction is significantly lower for whites in workplaces with a higher density of ethnic minority workers and that white male workers require a $12 \%$ wage premium to compensate them for having ethnic minority co-workers.

Frijters et al. (2006) is the only workplace based study investigating the link between workplace ethnic composition and job satisfaction. This paper aims to build on 
their study using the WERS2004 WERS data. In contrast to the WERS1998 data, which covered workplaces with 10 or more employees, WERS2004 monitored workplaces with 5 or more employees. Moreover, WERS2004 also has 8 different facets of job satisfaction, as opposed to the 4 facets monitored in WERS1998; and also renders a much larger (more than double) estimation sample than WERS1998. More importantly, the innovative estimation approach adopted in this paper compares levels of reported job satisfaction between whites working with and without ethnic minorities. Alternative markers of minority status have also been deployed in this paper based on whether information on minority status is provided by the employer or the employee; and whether minority status is defined at the workplace- or occupation-level. The rich approach adopted in this paper is likely to enhance our understanding of the link between workplace ethnic composition and job satisfaction.

\section{Data and variables}

\subsection{Overview of the Data}

The data used in this paper come from the 2004 British Workplace Employment Relations Survey (WERS2004), the most authoritative source of information on employment relations in Great Britain. It offers linked employeremployee data representative of all workplaces with five or more employees (Kersley et al. 2006). The survey covers a whole host of issues relating to both employers and employees, allowing us to control for a range of individual- and workplace-level characteristics.

\subsection{Definition of variables}

\subsubsection{Outcome variables}

The WERS2004 survey solicited employees' response on eight different facets of satisfaction, which are all related to aspects of their employment. The survey asked employees to rate - on a five-point scale from 'very satisfied' to 'very dissatisfied' - "how satisfied are you with the following aspects of your job": ( $\imath$ the sense of achievement they get from their work; (ii) the scope for using their own initiative; (iii) the amount of influence they have over their job; (iv) the training they receive; $(v)$ the amount of pay they receive; (vi) their job security; (vii) the work itself and (viii) their involvement in decision making. Reported levels of satisfaction on each of these facets with 5-point 
scores have then been recoded into $(-2,2)$ scales, where ' 2 ' is "very dissatisfied" and ' 2 ' is "very satisfied", before a single summative measure of job satisfaction is generated. As can be seen from the descriptive statistics in Table A1 in the Appendix, the summative job satisfaction outcome measure runs from $(-16,16)$.

\subsubsection{Markers of ethnic status and other control variables}

The paper uses three different markers of minority status. The first marker is a dummy variable 'minority employed, which is based on the employer response to the question "Of those currently employed here, how many...are from a non-white ethnic group?" The dummy assumes a value 1 if at least one minority is reported to be employed at the workplace and 0 otherwise. Thus, all white employees in workplaces where at least one minority is employed have a value 1 for the first minority marker variable. The second and third markers are both based on employees' response to the question "To which of these (ethnic) groups do you consider you belong?" Accordingly, if at least one employee in a workplace responded to be from a non-white ethnic background, all white employees in the workplace assume a value 1 for the dummy variable 'minority co-worker, workplace' and 0 otherwise. The third marker is a dummy 'minority co-worker, occupation', which assumes a value 1 for all white employees in a particular occupation if there is at least one co-worker in the occupation group is from a non-white ethnic background.

A number of other variables relating to employee and employer characteristics that include demographic, human capital, job, industry and geographic areas have been controlled for in the empirical analysis undertaken. Some of these variables such as the 'proportion of female employees in the workplace' and 'unemployment-to-vacancy ratio', which is defined on the basis of Travel to Work Area (TTWA) unemployment and vacancy rates, can also be considered to proxy job quality. In part due to gender discrimination, women tend to settle for relatively lower quality jobs vis-à-vis men. Given this, the proportion of women in a workplace can be used as a proxy for job quality. Table A2 in the Appendix reports descriptive statistics on all the control variables, including the three markers of workplace and co-worker minority status described above, which have been used in the regression analysis conducted.

\section{Empirical strategy}


The empirical strategy adopted in this paper is informed by theories of employee discrimination. The relevant explanations of interest are those that relate discrimination to either preference (Becker 1957; Arrow 1972, 1973; Phelps 1972) or information (Aigner and Cain 1977). iv Akerlof and Kranton (2000) formalized the earlier "taste" based discrimination explanations by incorporating identity into a model of behaviour and showing how identity influences economic outcomes. Their formulation is based on social identity theory that posits that an individual's social identity depends on all of the identifications the person uses in construing her/his views of the self. ${ }^{\mathrm{v}}$ According to these explanations, a person experiences anxiety when the person's internalised rules of personality (or identity) are violated somehow. Alesina and La Ferrara $(2000,2005)$ also note how diversity may affect economic choices by directly entering individual behaviour/preferences. Their formalization of the social identity theory based on group participation predicts that individual utility from joining a group depends positively on the share of group members of one's own type and negatively on the share of different types.

Based on Becker (1957) and Akerlof \& Kranton (2000), and building on Ragan and Tremblay (1988), this paper formulates a simple theoretical framework to study how natives' satisfaction may be influenced by the presence of minority co-workers:

Assumption 1: There are two groups of white workers: those with minority co-workers $(M)$ and those without $(N)$.

Assumption 2: White workers have a 'taste' for discrimination against minorities, whom they may regard as a threat.

Assumption 3: The influence of minority co-workers on whites' satisfaction does not vary with the level of the former.

The following simple prediction may follow, which forms the basis for the empirical analysis undertaken that;

$$
J S_{M}=(1-d * i) J S_{N}
$$


where $J S$ stands for reported job satisfaction; $0<d<1$ and $i=1$ if there is at least one minority co-worker at the workplace and 0 otherwise. Based on the simple relationship in equation (1), the following testable hypotheses can be developed:

Hypothesis 1: whites' satisfaction is negatively affected by the presence of minority co-workers.

This hypothesis will be tested on the basis of the estimated coefficient of the minority co-worker marker defined at the workplace- and occupation-levels.

Hypothesis 2: the link between whites' satisfaction and the presence of minority co-worker(s) is stronger the greater the proximity between the two.

This hypothesis will be tested on the basis of whether the estimated coefficient on the minority status marker is stronger at the workplace- or occupation-level, as defined on the basis of employees' response.

The paper assumes employees' reported job satisfaction proxies the level of utility they derive from their job, which can be specified as:

$$
U_{i j}=f\left(g_{j}, \boldsymbol{e} \boldsymbol{e}_{i j}, \boldsymbol{e r}_{j}\right), \quad i=1, \ldots, I \text { and } j=1, \ldots, J
$$

where $i$ and $j$ index employees and workplaces, respectively; $g$ represents the minority status of the workplace and/or occupation, $\boldsymbol{e} \boldsymbol{e}$ stands for a vector of employee's demographic, human capital and job related characteristics that includes levels of pay, and $\boldsymbol{e r}$ stands for a vector of workplace characteristics that include geographic location. The corresponding empirical model estimated has the general format given in equation (3) below.

$$
J S_{i j}=\boldsymbol{e} \boldsymbol{e}_{i j}^{\prime} \boldsymbol{\beta}_{e e}+\boldsymbol{e r}_{j}^{\prime} \boldsymbol{\beta}_{e r}+\delta g_{j}+u_{j}+\varepsilon_{i j}, \quad i=1, \ldots, I \text { and } j=1, \ldots, J
$$

where $J S$ represents employees' reported job satisfaction that represent underlying continuous latent measures of wellbeing, $J S_{i j}^{*}, u_{j}$ represents unmeasured workplace heterogeneity, and $\varepsilon_{i j}$ is the idiosyncratic error term. ${ }^{\mathrm{vi}}$ 
A simple comparison of the job satisfaction of natives with and without minority co-worker(s) may be misleading, if there is employee and/or employer sorting. To the extent that at least one of the employer and employee characteristics of native employees is correlated with the error, estimates obtained from equation (3) can be biased and inconsistent. However, this paper exploits the rich linked data to control for employee- and employer-level influences 'exhaustively', as well as accounting for unmeasured workplace heterogeneity, thereby minimising potential endogeneity problem. Moreover, the paper also implements a matching estimator (Rosenbaum and Rubin 1983), which balances on a broad range of employee and employer characteristics. ${ }^{\text {vii }}$ If one assumes observationally 'similar' employees to be sharing similar unobserved characteristics, the non-parametric matching estimator described below may render a preferred estimator.

Suppose that $J S^{1}$ and $J S^{0}$ represent the job satisfaction outcomes of whites with and without minority co-worker(s), respectively. Defining 'treatment' as white workers having at least one minority co-worker(s) $(\mathrm{D}=1)$ either at the workplace- or at the occupation-level as opposed to not having one $(\mathrm{D}=0)$, the causal effect of having a minority co-worker on whites' job satisfaction can be retrieved by matching whites with minority co-workers to 'similar' whites with no minority co-worker(s) to obtain the average treatment effect on the treated (ATT). The Conditional Independence Assumption (CIA) can be invoked to generate the counterfactual job satisfaction outcome of being in a workplace with no minority co-worker using the method of matching as:

$$
E\left(J S^{0} \mid D=1, P(X)\right)=E\left(J S^{0} \mid D=0, P(X)\right)
$$

where $P($.$) denote the probability scores of being white employee in a$ workplace or occupation with a minority co-worker, which are estimated on a rich set of employee and employer characteristics, $X$. Matching allows constructing the comparison group of whites in workplaces with no minority who resemble whites in workplaces with at least one minority co-worker(s). Under CIA, the average job satisfaction effect of being in a 'minority' workplace on whites (AT'T) can be retrieved as:

$$
\frac{1}{N^{1}} \sum_{i^{1} \in\{D=1\}}\left(\left(J S^{1}\right)_{i^{1}}-\sum_{i^{0} \in\{D=0\}} w_{i i^{10}}\left(J S^{0}\right)_{i^{0}}\right)
$$


where $\left(J S^{1}\right)_{i^{1}}$ is the job satisfaction of the $i^{1}$ th white employee in 'minority workplaces' $\left(i^{1} \in\{D=1\}\right) ;\left(J S^{0}\right)_{i^{0}}$ is the job satisfaction outcome of the $i^{0}$ th white employee in workplaces with no minority $\left(i^{0} \in\{D=0\}\right) ; w_{i^{1} i^{0}}$ is the weight of employees from workplaces with no minority $\sum_{i^{0} \in\{D=0\}} w_{i i^{0}}=1$ and $N^{1}$ is the number of white workers in 'minority workplaces' $i^{1}$. The counterfactual outcome is estimated using the weight function $w_{i^{1} i^{0}}$ in the sample of employees in workplaces with no minority, $i^{0}$, relative to the predicted propensity score $\hat{P(X)}$ of each 'treated' white employee $i^{1}$.

The matching method used in this paper is gaussian kernel matching with common support. It is implemented on propensity scores estimated using probit models that estimate the probability of being a white employee in a workplace with minority workers (i.e. with minority co-workers). Thus, employees from workplaces with no minority (the 'control' group) get weights according to their distance from whites in 'minority workplaces' (the 'treated' group) based on estimated propensity scores. ${ }^{\text {viii }}$

\section{Empirical results and discussion}

Results from the empirical analyses are reported in Tables 1 to 3 below. Table 1 reports initial regression results from estimation of the job satisfaction equation as specified in equation (3) on the full sample and minority status based sub-groups. The discussion focuses on the key variables of interest, which are the minority status indicator variables described in Section 3. Findings reported in Table 1 relate to the 'minority employed' marker. Controlling for a range of employee and employer characteristics that include measures of job quality, the estimated coefficient on the minority dummy is found to be negative and statistically significant, suggesting a reduction in job satisfaction in workplaces where there are ethnic minority workers.

'TABLE 1 here'

The coefficient in column (1) indicates a decline in job satisfaction of about 0.05 standard deviations for a one standard deviation increase in the employment of ethnic minorities. Sub-group based analyses reveal that the negative link found is almost 
exclusive to the white sub-group. However, the coefficient estimates for the white and minority sub-groups are not statistically different from each other.

Table 2 reports empirical findings based on the white sub-sample only and using all three markers of minority status. Column (1) reports results relating to the employer response based 'minority employed' marker, which are the same as those reported in column (2) of Table 1. Columns (2) and (3) report empirical results relating to the workplace- and occupation-level minority co-worker(s) indicators, which are both generated from employees' own responses as detailed in Section 3.

\section{'TABLE 2 here'}

The coefficient estimates on the workplace- and occupation-level minority coworker status markers both suggest that having ethnic minority co-worker(s) has a negative and statistically significant effect on the job satisfaction of whites. The estimated effects both indicate that there is a decline in the job satisfaction of whites with minority co-workers of about 0.03 standard deviations for a one standard deviation increase in the employment of ethnic minorities at the workplace- or occupation-level. These findings lend support to the first hypothesis developed in Section 4. It is worth noting that the findings reported in Table 2 control for job quality measures that include 'proportion of women employees' at the workplace and 'unemployment-to-vacancy ratio' defined on the basis of Travel to Work Area (TTWA) unemployment and vacancy rates.

Table 3 reports empirical findings from the alternative kernel based matching estimators. As detailed in the preceding Section, the matching estimator compares average job satisfaction outcomes of whites who work with ethnic minorities with that of 'comparable' whites who do not have minority co-worker(s). The matching approach reduces model dependence; and given the rich set of employee and employer characteristics the balancing has been performed on, the non-parametric matching based estimators may be preferred estimators. ${ }^{\text {ix }}$

'TABLE 3 here'

As can be seen from Table 3, the estimated coefficients from the matching estimators involving the three ethnic minority markers once again reveal that the job satisfaction of whites with minority co-workers is adversely affected by ethnic minority 
co-workers. This once again confirms the support provided to the first hypothesis as discussed earlier. Comparing the employee response based 'minority co-worker, workplace' and 'minority co-worker, occupation' markers reveals that the negative effect is stronger for the occupation-level marker. ${ }^{\mathrm{x}}$ This suggests that, on average, having ethnic minority co-worker(s) in one's occupation reduces job satisfaction a lot more than having such co-worker(s) at the workplace-level. Thus, it may be that, on average, the greater the proximity between natives and minority employees, the higher the reduction in the job satisfaction of natives. This finding is in line with the explanation of 'employee discrimination' and lends support to the second hypothesis developed in Section 4.

Turning to the other control variables in the model, the estimation results reported in Table 2 reveal two points worth noting. First, the coefficient estimates from the three specifications are robust to the type of minority marker deployed. In other words, whether the minority status is based on the employer or the employee response; or whether minority co-worker is defined at the workplace or occupation level does not affect the estimated coefficients on the other controls. Secondly, the results are very much in line with findings elsewhere in the literature. To mention just a few of these findings: older workers, women, the married and those with lower levels of educational attainment are found to be more satisfied vis-à-vis their respective counterparts while, on the other hand, those who have dependents, those with disability and those that are members of a trade union are found to have lower levels of satisfaction.

\section{Summary and Conclusion}

This paper attempted to establish empirically whether there is a link between co-worker minority status and natives' job satisfaction. It developed two testable hypotheses relating to the key question it attempted to answer, which have been developed on the basis of existing theoretical and empirical literature. The paper used the WERS2004 linked employer-employee data and alternative estimation strategy to establish the link between natives' job satisfaction and the presence of ethnic minority co-worker(s).

Three different measures of minority co-worker(s) status have been deployed, which are defined at the workplace- and occupation-level and based on both employer and employee responses. These measures are thought to capture varying degree of proximity between natives and minorities within the workplace setting. The results 
obtained lend support to the hypotheses proposed. In particular, having minority coworker(s) reduces the job satisfaction of natives, and the effect found is larger if the coworker-ship is at the occupation-level, rather than the workplace-level. The empirical analyses carried out controls for a battery of employee and workplace characteristics; and results obtained on these controls are in line with findings reported elsewhere in the literature concerning the factors determining job satisfaction. They are also found to be robust to the way minority status is defined.

The findings in this paper may be useful in informing the design and implementation of workplace policies and practices. As noted in Section 2, there are circumstances under which adverse effects of workplace ethnic diversity on team processes have been mitigated through training and development-focused initiatives. Such interventions may help improve employees' job satisfaction, promoting a healthy and more effective work environment. 


\section{References}

Aigner, D. and Cain, G. (1977). Statistical Theories of Discrimination in Labour Markets. Industrial and Labour Relations Review, 30 (2), 175-187.

Akerlof, G. A. and Kranton, R. E. (2000). Economics and Identity. The Quarterly Journal of Economics, 115 (3), 715-753.

Alesina, A. and La Ferrara, E. (2000). Participation in Heterogeneous Communities. Quarterly Journal of Economics, 115(3), 847-904.

Alesina, A. and La Ferrara, E. (2005) Ethnic Diversity and Economic Performance, Journal of Economic Literature, 43, 762-800

Arrow, K. (1972). Models of Job Discrimination. In Pascal, A (ed.) Racial Discrimination in Economic Life, Lexington, Massachusetts: D. C. Heath and Co.

Arrow, K. (1973). The theory of Discrimination. In Ashenfelter \& Rees (eds.) Discrimination in Labor Markets, Princeton: Princeton University Press.

Becker, G. (1971). The Economics of Discrimination, University of Chicago Press.

Berthoud, R. and Blekesaune, M. (2007). Persistent Employment Disadvantage. DWP Research Report 416. London: Department for Work and Pensions.

Blackaby, D., Leslie, D., Murphy, P. and O'Leary, N. (1999) Unemployment among Britain's ethnic minorities, Manchester School, 67, 1-20.

Blackaby, D., Leslie, D., Murphy, P. and O'Leary, N. (2002) White/ethnic minority earnings and employment differentials in Britain: evidence from the LFS, Oxford Economic Papers, 54, 270-297.

Blackabya, D., Leslieb, D., Murphya, P. and O'Learya, N. (2005) Born in Britain: How are native ethnic minorities faring in the British labour market? Economic Letters, $88,370-375$.

Blau, P. M. (1977). Inequality and Heterogeneity. New York: Free Press.

Clark, K. and Drinkwater, S. (2007) Ethnic Minorities in the labour market: dynamics and diversity, a report for the Joseph Rowntree Foundation, University of Manchester.

Daniels, K (2000). Measures of five aspects of affective well-being at work. Human Relations, 53 (2), 275 - 294.

EHRC (2008). Insight: Work fit for all - disability, health and the experience of negative treatment in the British workplace.

Frijters, P., Shields, M., Theodoropoulos, N. and Price, W. (2006) Testing for Employee Discrimination in Britain using Matched Employer-Employee Data. Discussion paper 2006-08, Department of Economics, University of Cyprus.

Heckman, J., Ichimura, H. and Todd, P. (1998) Matching as an Econometric Evaluation Estimator, Review of Economic Studies, 65, 261-294.

Kersley, B., Alpin, C., Forth, J., Bryson, A., Bewley, H., Dix, G. and Oxenbridge, S. (2006). Inside the Workplace: Findings from the 2004 Workplace Employment Relations Survey, Routledge, London.

Kochan T, Bezrukova K, Ely R, Jackson S, Joshi A, Jehn K, Leonard J, Levine D and Thomas D (2003). The Effects of Diversity on Business Performance: Report of the Diversity Research Work. Human Resource Management, 42 (1), 3-21.

Lang, K. (1986). A Language Theory of Discrimination. The Quarterly Journal of Economics, May 1986, 101 (2), 363-382.

Lazear, E. (1999). Globalisation and the market for team-mates. The Economic Journal, 109, C15-C40.

Leonard, J.S. and Levine, D.I. (2006). The Effect of Diversity on Turnover: A Large Case Study. Industrial \& Labor Relations Review, 59 (4), 547-572. 
Leslie, D. and Lindley, J. (2001) The impact of language ability on employment and earnings of Britain's ethnic communities, Economica, 68, 587- 606.

Pudney, S. and Shields, M. (2000) Gender and racial differentials in pay and promotion for NHS nurses. Oxford Bulletin of Economics and Statistics, 62, 01-833.

Ragan, J. F. and Tremblay, C. H. (1988). Testing for Employee Discrimination by Race and Sex. The Journal of Human Resources, 23 (1), 123-137.

Richard, O.C. (2000) Racial diversity, business strategy, and firm performance: a resource-based view, Academy of Management Journal, 43(2), 164-77.

Shields, M. A. and Price, S. W. (2002), Racial Harasment, Job Satisfaction and Intentions to Quit: Evidnece from the British Nursing Profession. Economica, 69, 5-326.

Strategy Unit (2003) Ethnic Minorities and the Labour Market, Cabinet Office.

Warr, P. (1999). Well-being and the Workplace. In Kahneman, D., Diener, E. and Schwarz, N. (eds.), Well-being: the foundations of hedonic psychology, Russell Sage Foundation, New York.

Wooldridge, J. M. (2002). Econometric Analysis of Cross Section and Panel Data, Massachusetts Institute of Technology. 
Table 1: Job satisfaction and minorities at the workplace, employer response based.

\begin{tabular}{|c|c|c|c|}
\hline & Full sample & White & Minority \\
\hline \multirow[t]{2}{*}{ Minority employed } & $-0.528^{* * *}$ & $-0.522 * * *$ & -0.389 \\
\hline & $(0.155)$ & $(0.155)$ & $(0.931)$ \\
\hline \multirow[t]{2}{*}{ Age $<30$} & $0.353 * *$ & $0.362^{* *}$ & 0.538 \\
\hline & $(0.148)$ & $(0.153)$ & $(0.609)$ \\
\hline \multirow[t]{2}{*}{ Age30-39 } & 0.155 & 0.177 & -0.226 \\
\hline & $(0.135)$ & $(0.137)$ & $(0.589)$ \\
\hline \multirow[t]{2}{*}{ Age50+ } & $0.532 * * *$ & $0.545^{* * *}$ & 0.575 \\
\hline & $(0.138)$ & $(0.136)$ & $(0.760)$ \\
\hline \multirow[t]{2}{*}{ Female } & $0.401 * * *$ & $0.443^{* * *}$ & -0.124 \\
\hline & $(0.119)$ & $(0.125)$ & $(0.463)$ \\
\hline \multirow[t]{2}{*}{ Married } & $0.479 * * *$ & $0.390^{* * *}$ & $1.911 * * *$ \\
\hline & $(0.114)$ & $(0.113)$ & $(0.575)$ \\
\hline \multirow[t]{2}{*}{ White } & -0.196 & & \\
\hline & $(0.323)$ & & \\
\hline \multirow{2}{*}{ Children $<7$ yrs old } & -0.077 & -0.050 & -0.597 \\
\hline & $(0.136)$ & $(0.139)$ & $(0.515)$ \\
\hline \multirow[t]{2}{*}{ Other dependents } & $-0.577 * * *$ & $-0.635^{* * *}$ & 0.205 \\
\hline & $(0.135)$ & $(0.136)$ & $(0.577)$ \\
\hline \multirow[t]{2}{*}{ Disabled } & $-0.818^{* * *}$ & $-0.785^{* * *}$ & $-1.277^{*}$ \\
\hline & $(0.148)$ & $(0.149)$ & $(0.767)$ \\
\hline \multirow[t]{2}{*}{ No academic qualification } & $0.526 * *$ & $0.682^{* * *}$ & $-1.793 * *$ \\
\hline & $(0.221)$ & $(0.214)$ & $(0.903)$ \\
\hline \multirow[t]{2}{*}{ O-level } & $0.416^{* *}$ & $0.510^{* * *}$ & -0.388 \\
\hline & $(0.175)$ & $(0.164)$ & $(0.652)$ \\
\hline \multirow[t]{2}{*}{ A-level } & 0.238 & 0.235 & 0.444 \\
\hline & $(0.189)$ & $(0.192)$ & $(0.674)$ \\
\hline \multirow[t]{2}{*}{ Other qualification } & 0.092 & 0.176 & -0.516 \\
\hline & $(0.158)$ & $(0.148)$ & $(0.585)$ \\
\hline \multirow[t]{2}{*}{ On permanent contract } & $1.091 * * *$ & $1.283^{* * *}$ & -0.647 \\
\hline & $(0.190)$ & $(0.191)$ & $(0.725)$ \\
\hline \multirow[t]{2}{*}{ Full-time } & $-0.509 * * *$ & $-0.697 * * *$ & $2.073^{* * *}$ \\
\hline & $(0.167)$ & $(0.167)$ & $(0.695)$ \\
\hline \multirow[t]{2}{*}{ Works over 48 hours } & $0.204 *$ & $0.246^{* *}$ & -0.499 \\
\hline & $(0.116)$ & $(0.118)$ & $(0.493)$ \\
\hline Skill same as required & $1.595^{* * *}$ & $1.621 * * *$ & $0.933^{* *}$ \\
\hline & $(0.097)$ & $(0.101)$ & $(0.403)$ \\
\hline Professional & $-1.520 * * *$ & $-1.527 * * *$ & -0.696 \\
\hline & $(0.231)$ & $(0.240)$ & $(0.973)$ \\
\hline Associate professional \& technical & $-1.564 * * *$ & $-1.540^{* * *}$ & -1.368 \\
\hline & $(0.196)$ & $(0.198)$ & $(0.918)$ \\
\hline Admin. \& secretarial & $-1.945^{* * *}$ & $-1.977 * * *$ & -1.439 \\
\hline & $(0.208)$ & $(0.211)$ & $(0.952)$ \\
\hline Skilled trades plant \& mach. & $-2.427 * * *$ & $-2.427 * * *$ & $-2.522 *$ \\
\hline & $(0.225)$ & $(0.221)$ & $(1.310)$ \\
\hline Personal \& customer services & $-1.970^{* * *}$ & $-2.029 * * *$ & -1.104 \\
\hline & $(0.219)$ & $(0.221)$ & $(0.890)$ \\
\hline Elementary occupations & $-1.977 * * *$ & $-2.103 * * *$ & -0.377 \\
\hline & $(0.259)$ & $(0.261)$ & $(1.079)$ \\
\hline Trade union member & $-1.143^{* * *}$ & $-1.145^{* * *}$ & $-1.047^{* *}$ \\
\hline & $(0.134)$ & $(0.136)$ & $(0.508)$ \\
\hline Gross weekly pay $<=110$ & 0.266 & 0.216 & 0.806 \\
\hline & $(0.245)$ & $(0.248)$ & $(0.957)$ \\
\hline Gross weekly pay $111-180$ & -0.221 & $-0.423^{*}$ & $1.864 * *$ \\
\hline & $(0.236)$ & $(0.220)$ & $(0.883)$ \\
\hline Gross weekly pay $261-360$ & -0.045 & -0.039 & 0.329 \\
\hline & $(0.167)$ & $(0.171)$ & $(0.693)$ \\
\hline Gross weekly pay 361p & $1.037 * * *$ & $1.074 * * *$ & 0.742 \\
\hline & $(0.182)$ & $(0.184)$ & $(0.758)$ \\
\hline Log work place age & -0.069 & -0.078 & 0.189 \\
\hline
\end{tabular}




\begin{tabular}{|c|c|c|c|}
\hline & $(0.068)$ & $(0.071)$ & $(0.212)$ \\
\hline \multirow[t]{2}{*}{ Sole establishment } & $1.046^{* * *}$ & $1.059^{* * *}$ & $1.362^{* *}$ \\
\hline & $(0.165)$ & $(0.169)$ & $(0.560)$ \\
\hline \multirow[t]{2}{*}{ No. of employees/1000 } & $-0.210^{* * *}$ & $-0.206^{* * *}$ & $-0.320^{*}$ \\
\hline & $(0.051)$ & $(0.051)$ & $(0.184)$ \\
\hline \multirow[t]{2}{*}{ Manufacturing } & -0.192 & -0.305 & $2.012^{* *}$ \\
\hline & $(0.289)$ & $(0.303)$ & $(0.783)$ \\
\hline \multirow[t]{2}{*}{ Construction } & $1.499 * * *$ & $1.470^{* * *}$ & 0.767 \\
\hline & $(0.361)$ & $(0.368)$ & $(0.824)$ \\
\hline \multirow[t]{2}{*}{ Wholesale \& retail trade } & $0.995^{* * *}$ & $0.933^{* * *}$ & $2.932^{* * *}$ \\
\hline & $(0.245)$ & $(0.251)$ & $(0.810)$ \\
\hline \multirow{2}{*}{ Hotel and restaurant } & $0.560^{*}$ & 0.373 & $3.439 * * *$ \\
\hline & $(0.306)$ & $(0.297)$ & $(1.241)$ \\
\hline \multirow[t]{2}{*}{ Public \& community services } & $0.571 * *$ & $0.551^{* *}$ & 1.136 \\
\hline & $(0.265)$ & $(0.273)$ & $(0.829)$ \\
\hline \multirow[t]{2}{*}{ Education } & $1.467^{* * *}$ & $1.470^{* * *}$ & $1.815^{*}$ \\
\hline & $(0.271)$ & $(0.272)$ & $(1.000)$ \\
\hline \multirow{2}{*}{ Health } & $1.771 * * *$ & $1.773^{* * *}$ & $2.278^{* *}$ \\
\hline & $(0.266)$ & $(0.269)$ & $(0.958)$ \\
\hline \multirow[t]{2}{*}{ Urban area } & -0.211 & -0.225 & -0.466 \\
\hline & $(0.196)$ & $(0.198)$ & $(1.109)$ \\
\hline \multirow[t]{2}{*}{ Unemployment to vacancy ratio } & -0.024 & -0.018 & 0.005 \\
\hline & $(0.032)$ & $(0.033)$ & $(0.086)$ \\
\hline \multirow[t]{2}{*}{ Proportion of female employees } & 0.586 & $0.618^{*}$ & 0.508 \\
\hline & $(0.390)$ & $(0.363)$ & $(1.581)$ \\
\hline \multirow[t]{2}{*}{ Constant } & $2.790^{* * *}$ & $2.571 * * *$ & -0.012 \\
\hline & $(0.664)$ & $(0.500)$ & $(2.120)$ \\
\hline No. of employees & 21258 & 20029 & 1229 \\
\hline No. of workplaces & 1661 & 1654 & 546 \\
\hline R-squared & 0.102 & 0.109 & 0.102 \\
\hline
\end{tabular}


Table 2: Job satisfaction and minority co-worker(s), whites only sample.

\begin{tabular}{|c|c|c|c|}
\hline & (1) & (2) & (3) \\
\hline \multirow[t]{2}{*}{ Minority employed } & $-0.522 * * *$ & & \\
\hline & $(0.155)$ & & \\
\hline \multirow{2}{*}{ Minority co-worker(s), workplace-level } & & $-0.368 * *$ & \\
\hline & & $(0.153)$ & \\
\hline \multirow{2}{*}{ Minority co-worker(s), occupation-level } & & & $-0.433 * *$ \\
\hline & & & $(0.169)$ \\
\hline \multirow{2}{*}{ Age $<30$} & $0.362^{* *}$ & $0.365^{* *}$ & $0.362^{* *}$ \\
\hline & $(0.153)$ & $(0.153)$ & $(0.153)$ \\
\hline \multirow[t]{2}{*}{ Age30-39 } & 0.177 & 0.186 & 0.180 \\
\hline & $(0.137)$ & $(0.137)$ & $(0.138)$ \\
\hline \multirow[t]{2}{*}{ Age 50+ } & $0.545^{* * *}$ & $0.559 * * *$ & $0.554 * * *$ \\
\hline & $(0.136)$ & $(0.136)$ & $(0.136)$ \\
\hline \multirow[t]{2}{*}{ Female } & $0.443^{* * *}$ & $0.446^{* * *}$ & $0.445^{* * *}$ \\
\hline & $(0.125)$ & $(0.125)$ & $(0.125)$ \\
\hline \multirow[t]{2}{*}{ Married } & $0.390^{* * *}$ & $0.398^{* * *}$ & $0.397 * * *$ \\
\hline & $(0.113)$ & $(0.113)$ & $(0.113)$ \\
\hline \multirow[t]{2}{*}{ Children $<7$ yrs old } & -0.050 & -0.051 & -0.046 \\
\hline & $(0.139)$ & $(0.139)$ & $(0.140)$ \\
\hline \multirow{2}{*}{ Other dependents } & $-0.635^{* * *}$ & $-0.640 * * *$ & $-0.638^{* * *}$ \\
\hline & $(0.136)$ & $(0.137)$ & $(0.137)$ \\
\hline \multirow[t]{2}{*}{ Disabled } & $-0.785^{* * *}$ & $-0.790 * * *$ & $-0.790 * * *$ \\
\hline & $(0.149)$ & $(0.150)$ & $(0.149)$ \\
\hline \multirow{2}{*}{ No academic qualification } & $0.682 * * *$ & $0.698^{* * *}$ & $0.698 * * *$ \\
\hline & $(0.214)$ & $(0.214)$ & $(0.214)$ \\
\hline \multirow[t]{2}{*}{ O-level } & $0.510^{* * *}$ & $0.519 * * *$ & $0.522^{* * *}$ \\
\hline & $(0.164)$ & $(0.164)$ & $(0.164)$ \\
\hline \multirow[t]{2}{*}{ A-level } & 0.235 & 0.251 & 0.252 \\
\hline & $(0.192)$ & $(0.192)$ & $(0.192)$ \\
\hline \multirow[t]{2}{*}{ Other qualification } & 0.176 & 0.179 & 0.180 \\
\hline & $(0.148)$ & $(0.149)$ & $(0.149)$ \\
\hline \multirow{2}{*}{ On permanent contract } & $1.283^{* * *}$ & $1.285^{* * *}$ & $1.278^{* * *}$ \\
\hline & $(0.191)$ & $(0.192)$ & $(0.192)$ \\
\hline \multirow[t]{2}{*}{ Full-time } & $-0.697 * * *$ & $-0.700^{* * *}$ & $-0.697 * * *$ \\
\hline & $(0.167)$ & $(0.167)$ & $(0.167)$ \\
\hline Works over 48 hours & $0.246^{* *}$ & $0.247 * *$ & $0.243^{* *}$ \\
\hline & $(0.118)$ & $(0.118)$ & $(0.118)$ \\
\hline Skill same as required & $1.621 * * *$ & $1.623^{* * *}$ & $1.623^{* * *}$ \\
\hline & $(0.101)$ & $(0.101)$ & $(0.101)$ \\
\hline Professional & $-1.527 * * *$ & $-1.519 * * *$ & $-1.486^{* * *}$ \\
\hline & $(0.240)$ & $(0.239)$ & $(0.241)$ \\
\hline Associate professional \& technical & $-1.540 * * *$ & $-1.529 * * *$ & $-1.499 * * *$ \\
\hline & $(0.198)$ & $(0.200)$ & $(0.201)$ \\
\hline Admin. \& secretarial & $-1.977 * * *$ & $-1.981 * * *$ & $-1.956^{* * *}$ \\
\hline & $(0.211)$ & $(0.213)$ & $(0.212)$ \\
\hline Skilled trades plant \& mach. & $-2.427 * * *$ & $-2.411^{* * *}$ & $-2.364 * * *$ \\
\hline & $(0.221)$ & $(0.221)$ & $(0.222)$ \\
\hline Personal \& customer services & $-2.029 * * *$ & $-2.046 * * *$ & $-2.011 * * *$ \\
\hline & $(0.221)$ & $(0.222)$ & $(0.222)$ \\
\hline Elementary occupations & $-2.103 * * *$ & $-2.118^{* * *}$ & $-2.077 * * *$ \\
\hline & $(0.261)$ & $(0.261)$ & $(0.259)$ \\
\hline Trade union member & $-1.145^{* * *}$ & $-1.166^{* * *}$ & $-1.151^{* * *}$ \\
\hline & $(0.136)$ & $(0.137)$ & $(0.137)$ \\
\hline Gross weekly pay $<=110$ & 0.216 & 0.237 & 0.250 \\
\hline & $(0.248)$ & $(0.249)$ & $(0.248)$ \\
\hline Gross weekly pay $111-180$ & $-0.423^{*}$ & $-0.427^{*}$ & $-0.416^{*}$ \\
\hline & $(0.220)$ & $(0.220)$ & $(0.219)$ \\
\hline Gross weekly pay $261-360$ & -0.039 & -0.052 & -0.052 \\
\hline & $(0.171)$ & $(0.171)$ & $(0.170)$ \\
\hline Gross weekly pay $361 p$ & $1.074 * * *$ & $1.059 * * *$ & $1.049 * * *$ \\
\hline
\end{tabular}




\begin{tabular}{|c|c|c|c|}
\hline & $(0.184)$ & $(0.183)$ & $(0.183)$ \\
\hline \multirow[t]{2}{*}{ Log work place age } & -0.078 & -0.090 & -0.091 \\
\hline & $(0.071)$ & $(0.070)$ & $(0.070)$ \\
\hline \multirow[t]{2}{*}{ Sole establishment } & $1.059 * * *$ & $1.099 * * *$ & $1.107 * * *$ \\
\hline & $(0.169)$ & $(0.168)$ & $(0.168)$ \\
\hline \multirow[t]{2}{*}{ No. of employees/1000 } & $-0.206 * * *$ & $-0.227 * * *$ & $-0.248^{* * *}$ \\
\hline & $(0.051)$ & $(0.052)$ & $(0.052)$ \\
\hline \multirow[t]{2}{*}{ Manufacturing } & -0.305 & -0.289 & -0.284 \\
\hline & $(0.303)$ & $(0.300)$ & $(0.300)$ \\
\hline \multirow[t]{2}{*}{ Construction } & $1.470^{* * *}$ & $1.544^{* * *}$ & $1.566^{* * *}$ \\
\hline & $(0.368)$ & $(0.362)$ & $(0.363)$ \\
\hline \multirow[t]{2}{*}{ Wholesale \& retail trade } & $0.933^{* * *}$ & $1.007 * * *$ & $1.019 * * *$ \\
\hline & $(0.251)$ & $(0.250)$ & $(0.250)$ \\
\hline \multirow{2}{*}{ Hotel and restaurant } & 0.373 & 0.373 & 0.391 \\
\hline & $(0.297)$ & $(0.294)$ & $(0.294)$ \\
\hline \multirow[t]{2}{*}{ Public \& community services } & $0.551^{* *}$ & $0.602 * *$ & $0.605^{* *}$ \\
\hline & $(0.273)$ & $(0.274)$ & $(0.272)$ \\
\hline \multirow[t]{2}{*}{ Education } & $1.470^{* * *}$ & $1.472^{* * *}$ & $1.462^{* * *}$ \\
\hline & $(0.272)$ & $(0.274)$ & $(0.275)$ \\
\hline \multirow[t]{2}{*}{ Health } & $1.773^{* * *}$ & $1.791 * * *$ & $1.764^{* * *}$ \\
\hline & $(0.269)$ & $(0.271)$ & $(0.271)$ \\
\hline \multirow[t]{2}{*}{ Urban area } & -0.225 & -0.259 & -0.284 \\
\hline & $(0.198)$ & $(0.196)$ & $(0.193)$ \\
\hline \multirow{2}{*}{ Unemployment to vacancy ratio } & -0.018 & -0.013 & -0.016 \\
\hline & $(0.033)$ & $(0.033)$ & $(0.033)$ \\
\hline \multirow[t]{2}{*}{ Proportion of female employees } & $0.618^{*}$ & $0.680^{*}$ & $0.716^{* *}$ \\
\hline & $(0.363)$ & $(0.360)$ & $(0.360)$ \\
\hline \multirow[t]{2}{*}{ Constant } & $2.571 * * *$ & $2.362 * * *$ & $2.300^{* * *}$ \\
\hline & $(0.500)$ & $(0.493)$ & $(0.491)$ \\
\hline No. of employees & 20029 & 20029 & 20029 \\
\hline No. of workplaces & 1654 & 1654 & 1654 \\
\hline R-squared & 0.109 & 0.108 & 0.108 \\
\hline
\end{tabular}


Table 3: Job satisfaction and minority co-worker, matching based estimators, whites only sample

\begin{tabular}{|c|c|c|c|}
\hline & Observed & Bootstrap & \\
\hline & Coef. & Std. Err. & $\mathrm{z}$ \\
\hline \multicolumn{4}{|l|}{ Minority employed } \\
\hline ATT & -0.623 & 0.176 & -3.55 \\
\hline \multicolumn{4}{|c|}{ Minority co-worker(s) at workplace-level } \\
\hline ATT & -0.458 & 0.170 & -2.69 \\
\hline \multicolumn{4}{|c|}{ Minority co-worker(s) at occupation-level } \\
\hline $\mathrm{ATT}$ & -0.607 & 0.182 & -3.34 \\
\hline Number of employees & 20029 & & \\
\hline
\end{tabular}

Bootstrap standard errors from 250 replications based on 1034 clusters/workplaces. 


\section{Appendix:}

Table A1: Summative job satisfaction and its eight constituent facets.

\begin{tabular}{lllllllllllll}
\hline & All & \multicolumn{3}{c}{ White } & \multicolumn{7}{c}{ Minority } \\
\hline Variable & Mean & $\begin{array}{l}\text { Std. } \\
\text { Dev. }\end{array}$ & Min & Max & Mean & $\begin{array}{l}\text { Std. } \\
\text { Dev. }\end{array}$ & Min & Max & Mean & $\begin{array}{l}\text { Std. } \\
\text { Dev. }\end{array}$ & Min & Max \\
Job Satisfaction & & & & & & & & & & & & \\
Achievement & 0.740 & 0.963 & -2 & 2 & 0.740 & 0.961 & -2 & 2 & 0.736 & 0.995 & -2 & 2 \\
Initiative & 0.767 & 0.974 & -2 & 2 & 0.772 & 0.966 & -2 & 2 & 0.687 & 1.082 & -2 & 2 \\
Influence & 0.490 & 0.998 & -2 & 2 & 0.495 & 0.992 & -2 & 2 & 0.416 & 1.087 & -2 & 2 \\
Training & 0.273 & 1.113 & -2 & 2 & 0.269 & 1.109 & -2 & 2 & 0.335 & 1.183 & -2 & 2 \\
Pay & -0.113 & 1.140 & -2 & 2 & -0.109 & 1.139 & -2 & 2 & -0.184 & 1.147 & -2 & 2 \\
Job security & 0.491 & 1.076 & -2 & 2 & 0.499 & 1.071 & -2 & 2 & 0.369 & 1.142 & -2 & 2 \\
Work itself & 0.744 & 0.937 & -2 & 2 & 0.750 & 0.934 & -2 & 2 & 0.645 & 0.988 & -2 & 2 \\
Decision making & 0.168 & 1.016 & -2 & 2 & 0.172 & 1.015 & -2 & 2 & 0.111 & 1.026 & -2 & 2 \\
Summative job & 3.307 & 5.704 & -16 & 16 & 3.336 & 5.694 & -16 & 16 & 2.838 & 5.845 & -16 & 16 \\
satisfaction & & & & & & & & & & & & \\
No. of employees & 21258 & & & & 20029 & & & & 1229 & & & \\
No. of workplaces & 1661 & & & & 1115 & & & & 546 & & & \\
\hline
\end{tabular}


Table A2: Summary of employee \& employer characteristics

\begin{tabular}{|c|c|c|c|c|c|c|}
\hline & All & & White & & Minority & \\
\hline Variable & Mean & Std. Dev. & Mean & Std. Dev. & Mean & Std. Dev. \\
\hline Minority employed & 0.654 & 0.476 & 0.639 & 0.480 & 0.908 & 0.289 \\
\hline Minority co-worker, workplace-level & 0.379 & 0.485 & 0.340 & 0.474 & 1.000 & 0.000 \\
\hline Minority co-worker, occupation-level & 0.200 & 0.400 & 0.151 & 0.358 & 1.000 & 0.000 \\
\hline Age $<30$ & 0.213 & 0.409 & 0.206 & 0.405 & 0.319 & 0.466 \\
\hline Age30-39 & 0.251 & 0.433 & 0.248 & 0.432 & 0.299 & 0.458 \\
\hline Age50+ & 0.268 & 0.443 & 0.275 & 0.447 & 0.151 & 0.358 \\
\hline Female & 0.532 & 0.499 & 0.532 & 0.499 & 0.539 & 0.499 \\
\hline Married & 0.678 & 0.467 & 0.683 & 0.465 & 0.602 & 0.490 \\
\hline White & 0.942 & 0.233 & 1.000 & 0.000 & 0.000 & 0.000 \\
\hline Children $<7$ yrs old & 0.177 & 0.382 & 0.172 & 0.377 & 0.270 & 0.444 \\
\hline Other dependents & 0.162 & 0.368 & 0.161 & 0.368 & 0.167 & 0.373 \\
\hline Disabled & 0.120 & 0.326 & 0.122 & 0.327 & 0.095 & 0.294 \\
\hline No. academic qualification & 0.158 & 0.365 & 0.160 & 0.367 & 0.132 & 0.338 \\
\hline O-level & 0.229 & 0.420 & 0.232 & 0.422 & 0.181 & 0.386 \\
\hline A-level & 0.090 & 0.286 & 0.090 & 0.286 & 0.088 & 0.283 \\
\hline Other qualification & 0.339 & 0.473 & 0.339 & 0.473 & 0.334 & 0.472 \\
\hline On permanent contract & 0.919 & 0.272 & 0.923 & 0.266 & 0.855 & 0.352 \\
\hline Full-time & 0.781 & 0.413 & 0.781 & 0.414 & 0.788 & 0.409 \\
\hline Works over 48 hours & 0.461 & 0.498 & 0.459 & 0.498 & 0.492 & 0.500 \\
\hline Skill same as required & 0.420 & 0.494 & 0.423 & 0.494 & 0.369 & 0.483 \\
\hline Professional & 0.119 & 0.324 & 0.120 & 0.325 & 0.111 & 0.314 \\
\hline Associate professional \& Technical & 0.163 & 0.370 & 0.162 & 0.368 & 0.189 & 0.391 \\
\hline Admin. \& secretarial & 0.186 & 0.389 & 0.189 & 0.391 & 0.146 & 0.354 \\
\hline Skilled trades plant \& mach. & 0.144 & 0.351 & 0.145 & 0.352 & 0.137 & 0.344 \\
\hline Personal \& customer services & 0.155 & 0.362 & 0.153 & 0.360 & 0.185 & 0.388 \\
\hline Elementary occupations & 0.120 & 0.325 & 0.117 & 0.322 & 0.167 & 0.373 \\
\hline Trade union member & 0.361 & 0.480 & 0.366 & 0.482 & 0.275 & 0.447 \\
\hline Gross weekly pay $<=110$ & 0.099 & 0.299 & 0.099 & 0.298 & 0.107 & 0.309 \\
\hline Gross weekly pay $111-180$ & 0.102 & 0.302 & 0.100 & 0.301 & 0.120 & 0.325 \\
\hline Gross weekly pay $261-360$ & 0.206 & 0.404 & 0.206 & 0.405 & 0.203 & 0.403 \\
\hline Gross weekly pay $361 p$ & 0.408 & 0.491 & 0.411 & 0.492 & 0.352 & 0.478 \\
\hline Log work place age & 3.239 & 1.144 & 3.245 & 1.146 & 3.143 & 1.119 \\
\hline Sole establishment & 0.207 & 0.405 & 0.209 & 0.407 & 0.175 & 0.380 \\
\hline No. of employees/1000 & 0.420 & 0.890 & 0.417 & 0.884 & 0.473 & 0.978 \\
\hline Manufacturing & 0.153 & 0.360 & 0.153 & 0.360 & 0.149 & 0.356 \\
\hline Construction & 0.048 & 0.214 & 0.050 & 0.218 & 0.017 & 0.130 \\
\hline Wholesale \& retail trade & 0.098 & 0.297 & 0.097 & 0.296 & 0.106 & 0.308 \\
\hline Hotel and restaurant & 0.090 & 0.286 & 0.089 & 0.284 & 0.108 & 0.311 \\
\hline Public \& community services & 0.159 & 0.365 & 0.162 & 0.369 & 0.104 & 0.306 \\
\hline Education & 0.121 & 0.326 & 0.122 & 0.327 & 0.111 & 0.314 \\
\hline Health & 0.162 & 0.368 & 0.158 & 0.365 & 0.229 & 0.420 \\
\hline Urban area & 0.826 & 0.379 & 0.820 & 0.384 & 0.934 & 0.248 \\
\hline Unemployment to vacancy ratio & 3.390 & 2.392 & 3.294 & 2.315 & 4.964 & 2.998 \\
\hline Proportion of females & 0.511 & 0.288 & 0.510 & 0.289 & 0.530 & 0.275 \\
\hline No. of employees (\%) & 21258 & & $20029(94)$ & & $1229(6)$ & \\
\hline No. of workplaces $(\%)$ & 1661 & & $1115(67)$ & & $546(33)$ & \\
\hline
\end{tabular}


${ }^{i}$ The first race relations act, which was designed to address racial discrimination, came into effect in 1965.

ii The increase is attributed to successive inflows of migrants in the Post World War II period for the most part (Clark and Drinkwater 2007, Blackaby et al. 2005, Strategy Unit 2003); one also expects globalisation to have played a part in boosting the increase in more recent decades.

iii Kochan et al. (2003) report adverse effects of racial diversity on team processes being mitigated through training and development-focused initiatives.

iv The 'taste' explanation stipulates racial discrimination occurs when people behave as if they refuse to change their stereotypes about the capabilities of discriminated individuals or groups, which may not change even in the face of favourable information about the group. The information explanation (Aguero 2005) states that discrimination is the result of asymmetric information about discriminated individual \& such stereotypes alter with information. Other, theories of relevance include language based discrimination (Lang 1986) \& Lazear (1999)'s communication costs explanation of diversity.

v Similar explanations can be found in Tajfel 1982, Turner 1987, Stone-Romero et al., 2006.

vi This is done with the cluster option to account for the presence of at least two employees from same workplace.

vii The matching estimator assumes the outcome of interest (job satisfaction) to be independent of participation status conditional on a set of observable characteristics (Heckman, Ichimura, and Todd 1998). viii Larger weights are thus assigned to natives from workplaces with no minority who are 'close' to natives in workplaces with minorities as measured by these propensity scores.

ix Coefficient estimates from the relevant probit equations estimated and covariate balance test results are available on request.

$\mathrm{x}$ It is not possible to determine the occupation of minorities from the employer response. So the only judicious comparison that can be made between workplace- and occupation-level minority statuses is based on employees' response. 